\title{
Canine coronavirus infection in dogs in Turkey: Virological and serological evidence
}

\author{
Oguzhan Avci*, Oya Bulut, Orhan Yapici ${ }^{1}$, Sibel Hasircioglu ${ }^{2}$ and Atilla Simsek \\ Department of Virology, Faculty of Veterinary Medicine, \\ Selcuk University, 42003, Konya, Turkey. \\ Received: 27-02-2016 \\ Accepted: 26-04-2016
}

DOI:10.18805/ijar. 11173

\section{ABSTRACT}

In the present study, virological and serological investigations were performed to determine the presence and prevalence of Canine corona virus $(\mathrm{CCoV})$ infection in dog population in Turkey. Sera samples were analyzed for specific antibodies against $\mathrm{CCoV}$ by indirect enzyme linked immunosorbent assay (i-ELISA) while leukocyte samples were inoculated onto monolayers of Madin Darby Canine Kidney permanent cell culture. The cells were examined for viral antigen by direct immunofluorescence (IF) test after third passage. CCoV seropositivity was found in $46(24.46 \%)$ of 188 dogs by indirect ELISA while only one leukocyte sample $(0.53 \%)$ was detected as antigen positive by IF. Seropositive and antigen identification results were considered as indication of infection. From the results of this study it can be concluded that $\mathrm{CCoV}$ infection is widespread in the Turkish dog population and the virus may be attributed to be one of the important viral agents in dogs. In conclusion diagnosis of $\mathrm{CCoV}$ is difficult because it can easily be mixed with respiratory, enteric and generalized infections by other viral, bacterial and parasitic agents, but diagnosis and the vaccine application are essential for the control and prevention of CCoV infections.

Key words: CCoV, Dog, Immunofluorescence, i-ELISA, Sera.

\section{INTRODUCTION}

The emergence of human severe acute respiratory syndrome encouraged renewed interest in animal coronaviruses as potential agents of direct and indirect zoonosis and has new attention focused on coronaviruses. Coronaviruses are large viruses that cause respiratory, enteric and generalized disease in humans and domestic animals (Chinese SARS Molecular Epidemiology Consortium 2004, Slingenbergh et al., 2004; Lau et al., 2005). Coronaviruses, Nidovirales order, have single stranded positivesense genomic RNA (De Vries et al., 1997; Decaro and Buonavoglia 2008).

Canine coronavirus (CCoV) belongs to one of the major antigenic groups of coronaviruses (Lai and Holmes 2001; Pratelli, 2011; Costa et al., 2014). CCoV, first described by Binn et al. (1974), can affect both domestic and wild dogs worldwide (Decaro and Buonavoglia, 2008; Priestnall et al., 2014). Mild disease or asymptomatic carriages are probably in many cases common outcomes of infection (Graham and Baric 2010). To date, two different genotypes of $\mathrm{CCoV}$ are known, $\mathrm{CCoV}$ type I (CCoV-I) and $\mathrm{CCoV}$ type II (CCoV-II). CCoV type II is divided in two subtypes, CCoV-IIa (classical strains) and CCoV-IIb, with $\mathrm{CCoV}$-IIb emerging as a result of a putative recombination between CCoV-IIa and transmissible gastroenteritis virus (TGEV) (Ntafis et al., 2013).
Different serologic (indirect ELISA, microneutralization) (Mochizuki et al., 1987; Tuchiya et al., 1991; Elia et al., 2003; Buonavoglia et al., 2006; Le Poder, 2011) and virologic (direct ELISA, cell culture, direct immunofluorescence) diagnostic methods are widely used to detect the genotypes of CCoV (Costa et al., 2014).

In the present study, it has been hypothesized that $\mathrm{CCoV}$ infection which reported from different region of Turkey may affect dogs in Konya, Isparta and Burdur. The aim of this study was to determine the serological and virological status of $\mathrm{CCoV}$ infection in mentioned provinces.

\section{MATERIALS AND METHODS}

Animals: Blood samples were collected from $111 \mathrm{dogs}$ showing clinical symptoms which were admitted to the Internal Medicine Clinic of Faculty of Veterinary Medicine, Selcuk University, and from 77 unvaccinated dogs, which were housed at dog shelters in Isparta (n: 49) and Burdur (n: 28) provinces and were randomly sampled irrespective of their displaying clinical signs.

Indirect ELISA tests: Serum samples were tested for specific antibodies against $\mathrm{CCoV}$ by commercially available indirect enzyme linked immunosorbent assay (EVL/ European Veterinary Laboratory, Catalog no: D1005-AB01, Netherlands) kit. The test was performed according to the manufacturer's instructions and assessed using automatic ELISA plate reader (Rayto RT-2100C, China) 450nm filter.

*Corresponding author's e-mail: oavci@ selcuk.edu.tr. ${ }^{1}$ Department of Preclinical Sciences, Faculty of Veterinary Medicine, Kyrgyzstan-Turkey Manas University, 720044, Bishkek, Kyrgyzstan. ${ }^{2}$ Department of Virology, Faculty of Veterinary Medicine, Mehmet Akif Ersoy University, 15030, Burdur, Turkey. 
Results were analyzed on the basis of the optical densities values of samples using (\%) positive and negative control wells.

Cell culture: Madin Darby Canine Kidney (MDCK) permanent cells were grown in Dulbecco's Minimum Essential Medium (DMEM, Biological Industries, Israel) supplemented with $100 \mathrm{U}$ of penicillin/mL, $100 \mu \mathrm{g}$ of streptomycin $/ \mathrm{mL}$ and $5 \%$ fetal calf serum (Biological Industries, Israel) for $\mathrm{CCoV}$ isolation. The cells were incubated in an atmosphere of $5 \% \mathrm{CO}_{2}$ incubator (Nuve, Turkey) at $37^{\circ} \mathrm{C}$.

Blood samples: Blood samples were drawn into sterile tubes with EDTA. Leukocyte samples were prepared by a standard method (Bas and Demet, 1992) and were kept on $-20^{\circ} \mathrm{C}$ until being used. Leukocyte samples were analyzed for $\mathrm{CCoV}$ antigens by direct immunofluorescence (IF) test after third blind passage on monolayers of MDCK permanent cell culture system.

Direct immunofluorescence: For the IF test, the leukocyte samples inoculated into the 24-well micro plates were retrieved from $-20^{\circ} \mathrm{C}$ and thawed in a water bath at $37^{\circ} \mathrm{C}$. The third blind passages of the leukocyte samples grown in MDCK cell culture were made in 24-well micro plates. Each well of the Lab-Tek chamber slides procured from Thermo Fisher Scientific (USA, Catalogue no. 178599) was inoculated with $200 \mu \mathrm{L}$ of MDCK cells. Next, the slides were incubated at $37^{\circ} \mathrm{C}$ for 24 hours. Later, $20 \mu \mathrm{L}$ of the third-passage fluid of each leukocyte sample was inoculated into two wells. After adsorption period (24hour), the cell surfaces were rinsed with phosphate buffer solution (PBS) and $200 \mu \mathrm{L}$ of medium without serum was added to each well. At the end of the third day, the medium was removed and the ready-to-use $\mathrm{CCoV}$ conjugate procured from VMRD (USA, Catalogue no. CJ-F-CCV-10 mL) was added to all wells, and the slides were incubated in humid chamber at $37^{\circ} \mathrm{C}$ for $30 \mathrm{~min}$. After incubation period, the conjugate was removed from the micro plates wells, and the cells were rinsed with FA Rinse Buffer, pH 9.0 (VMRD catalogue no. 210-90-RB) for three times and allowed $10 \mathrm{~min}$ for drying. $50 \mu \mathrm{L}$ of $90 \%$ glycerol solution was added to each well. Finally, the wells were examined under a fluorescence microscope (Olympus Bx51, Japan).

Statistical analysis: Results of this study amongst provinces, sex, and breeds were calculated by using chi-square test (Minitab 14.0 Inc., State College, PA, USA). Difference were considered significant when $\mathrm{P}<0.05$.

\section{RESULTS AND DISCUSSION}

A total of $46(24.46 \%)$ from 188 dogs were detected as seropositive for $\mathrm{CCoV}$ antibodies by indirect ELISA (Table 1$)$. Only one leukocyte sample $(0.53 \%)$ from 2 years old male dog from Burdur province, was detected as antigen positive by IF (Fig. 1, Fig. 2) while antibody against $\mathrm{CCoV}$ was negative. There was no statistical significance when $\mathrm{CCoV}$ antigen was determined between female (31/67) and male (15/65), whereas existence of $\mathrm{CCoV}$ antigen in street $\operatorname{dog}(46 / 111)$ was higher $(\mathrm{P}<0.05)$ than owned dogs $(0 / 31)$.

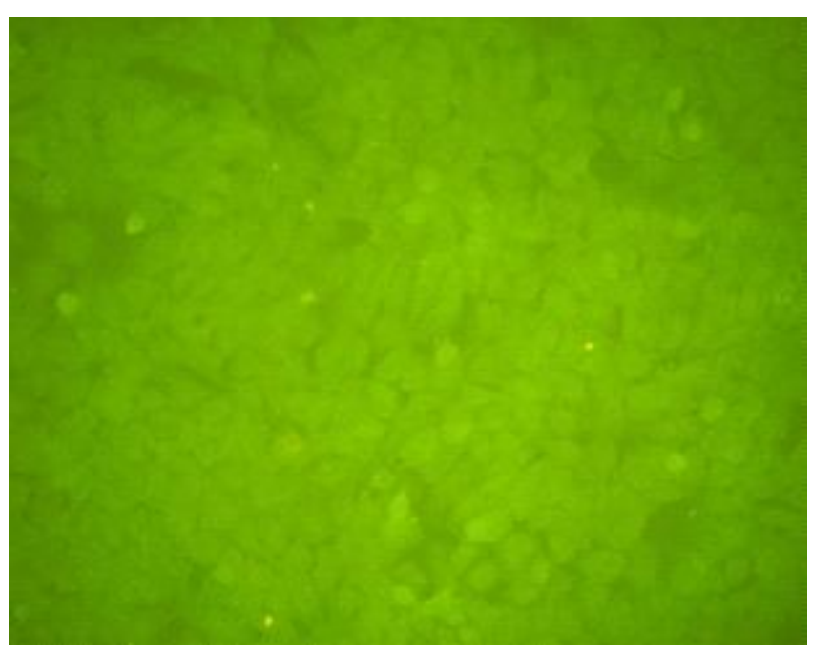

Fig 1: MDCK cell control (X40).

Table 1: Prevalence of $\mathrm{CCoV}$ according to province, breed, and sex.

\begin{tabular}{|c|c|c|c|c|c|}
\hline Provinces & Breed & No of samples & Sex & Male/Female & Total +/- \\
\hline \multirow[t]{10}{*}{ Konya } & Siberian Husky & 2 & - & 2 & $13 / 98^{\mathrm{a}}(\mathrm{n}: 111)$ \\
\hline & Cross breed with Pitbull & 2 & 1 & 1 & \\
\hline & Akbas dog & 1 & - & 1 & \\
\hline & Kars Shepherd dog & 1 & 1 & - & \\
\hline & Crossbreed with Kangal & 21 & 6 & 15 & \\
\hline & Spanish cocker & 1 & 1 & - & \\
\hline & Pointer & 1 & - & 1 & \\
\hline & Terrier & 1 & - & 1 & \\
\hline & Beagle & 1 & - & 1 & \\
\hline & Street dog & 80 & 37 & 43 & \\
\hline Isparta & Street dog & 49 & 19 & 30 & $18 / 31^{\mathrm{b}}(\mathrm{n}: 49)$ \\
\hline Burdur* & Street dog & 28 & 15 & 13 & $15 / 13^{\mathrm{b}}(\mathrm{n}: 28)$ \\
\hline Total & & 188 & 80 & 108 & 188 \\
\hline
\end{tabular}

a, b: Different letters in same column are statistically significant $(\mathrm{P}<0.001)$ 


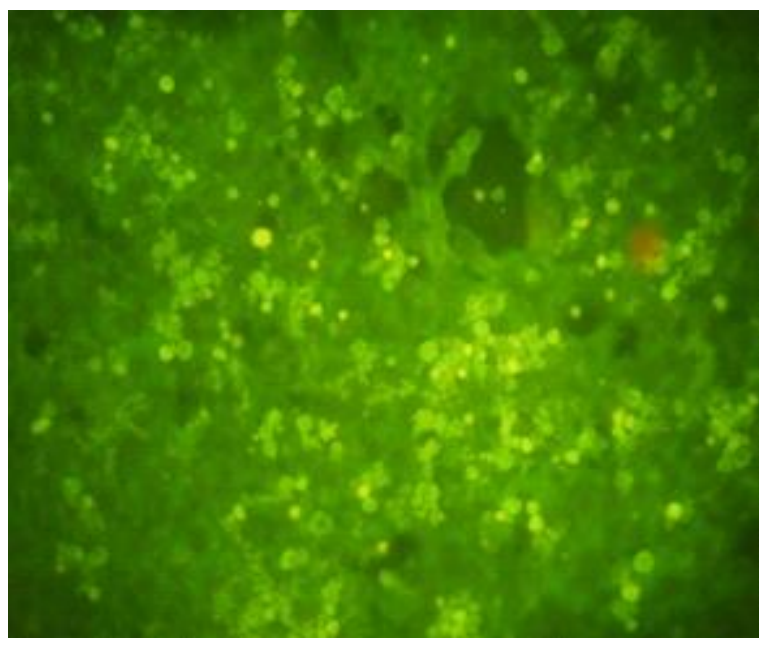

Fig 2: Antigen positive sample by IF (X40).

Canine Coronavirus is generally reported from dogs with gastroenteritis but mix infections by canine parvovirus (CPV) have been detected in the recent years (Evermann $e t$ al., 2005; Bodewes and Egberink, 2009). Different laboratory diagnostic tests can be used for specific antibody detection, but generally two tests [ELISA (Tuchiya et al., 1991; Gur et al., 2008; Ellis et al., 2011) and Virus Neutralization (Mochizuki et al., 1987)] have been widely used for detection of CCoV. Serum neutralization tests (Huxsoll et al., 2006) and direct florescence antibody test (dFAT) (Hansa et al., 2012) can also be used for definitive diagnosis of CCoV.

The results in the present study are the first evidence for $\mathrm{CCV}$ infection on dogs in Isparta and Burdur provinces. Serologic diagnosis of CCV in Kangal dogs in Konya have been reported earlier by Gur et al. (2008) but in the present study, only street dogs were determined as seropositive for $\mathrm{CCV}$ infection in Konya, Isparta and Burdur. All of owned dogs were negative by both serologic and virologic tests. When provinces were compared there was no statistical difference in CCV infections likely to be seen in dogs between Isparta and Burdur while the lowest serologic results were obtained from Konya $(\mathrm{P}<0.001)$. Also, there was no statistical differences between sex in CCV infection in dogs $(\mathrm{P}>0.05)$.

$\mathrm{CCoV}$ infection have been reported from different countries Turkey (Gur et al., 2008), Italy (Decaro et al., 2012), Greece (Ntafis et al., 2012), Belgium (Zicola et al., 2012), and detection has been reported from different specimens such as intestinal system (Keenan et al., 1976), feces (Battersby and Harvey, 2006; Ntafis et al., 2013; Costa et al., 2014), and internal organs like liver, lung, mesenteric lymph node and thymus (Ntafis et al., 2013). CCoV viral RNA detection from blood sample was reported by Decaro et al. (2010) from one experimentally infected by $\mathrm{CB} / 05$ on dog (Decaro and Buonavoglia, 2011) during viremia. Leukocyte positive result obtained from this research is in accordance with the results of other researchers (Decaro and Buonavoglia, 2011). Positive dog had been evaluated on viremia phase of infection. Hence, as per knowledge $\mathrm{CCoV}$ detection from leukocyte was reported for the first time.

According to the seropositive (indicated as natural infection because unvaccinated street dogs were used) and antigen positive results of this study, it can be concluded that $\mathrm{CCoV}$ infection in Turkish street dog population is widespread and it may be attributed to be one of important viral pathogens in dogs. Findings obtained from this research showed that all owned animals were antigen negative. These results indicated that vaccination for CCV could be the most useful programme for prevention from CCV infection. In conclusion, $\mathrm{CCoV}$ infections can easily occur as mix infections with other pathogens such as viral, bacterial or parasitic agents. Hence, rapid diagnosis and the vaccination application as soon as possible are essential for the control of $\mathrm{CCoV}$ epidemics.

\section{ACKNOWLEDGMENTS}

The abstract of this study was published in the $20^{\text {th }}$ FECAVA Eurocongress, Munich, Germany, 2014.

\section{REFERENCES}

Bas, A.L. and Demet, O. (1992). Investigation of effects chloramphenicol on bovine polymorphonuclear leucocytes (PMNL) functions in vitro and in vivo. Eurasian J. Vet. Sci. 19: 73-80.

Battersby, I. and Harvey, A. (2006). Differential diagnosis and treatment of acute diarrhoea in the dog and cat. In Practice. 28: $480-488$.

Binn, L.N., Lazar, E.C., Kenan, K.P., Huxsoll, D.L., Marchwicki, R.H. and Strano, A.J. (1974). Recovery and characterization of a corona virus from military dogs with diarrhea. Proc. Annu. Meet. U. S. Anim. Health Assoc. 78: $359-366$.

Bodewes, R. and Egberink, H.F. (2009). An update on viral diseases of the dog and cat. Tijdschr Diergeneeskd. 134: 330-336.

Buonavoglia, C., Decaro, N., Martella, V., Elia, G., Campolo, M., Desario, C., Castagnaro, M. and Tempesta, M. (2006). Canine coronavirus highly pathogenic for dogs. Emerg. Infect. Dis. 12: 492-494.

Chinese SARS Molecular Epidemiology Consortium. (2004). Molecular evolution of the SARS coronavirus during the course of the SARS epidemic in China. Science. 303: 1666-1669.

Costa, E.M., de Castro, T.X., BottinoFde, O. and Garcia Rde, C. (2014). Molecular characterization of canine coronavirus strains circulating in Brazil. Vet. Microbiol. 168: 8-15. 
De Vries, A.A.F., Horzinek, M.C., Rottier, P.J.M. and De Groot, R.J. (1997). The genome organization of the Nidovirales: similarities and differences between arteri-, toro- and corona viruses. Semin. Virol. 8: 33-47.

Decaro, N. and Buonavoglia, C. (2008). An update on canine coronaviruses: viral evolution and pathobiology. Vet. Microbiol. 10: 221-234.

Decaro, N. and Buonavoglia, C. (2011). Canine coronavirus: not only an enteric pathogen. Vet. Clin. North Am. Small Anim. Pract. 41: 1121-1132.

Decaro, N., Mari, V., von Reitzenstein, M., Lucente, M.S., Cirone, F., Elia, G., Martella, V., King, V.L., Di Bello, A., Varello, K., Zhang, S., Caramelli, M. and Buonavoglia, C. (2012). A pantropic canine coronavirus genetically related to the prototype isolate CB/05. Vet. Microbiol. 159: 239-244.

Decaro, N., Cirone, F., Mari, V., Nava, D., Tinelli, A., Elia, G., Di Sarno, A., Martella, V., Colaianni, M.L., Aprea, G., Tempesta, M. and Buonavoglia, C. (2010). Characterisation of bubaline coronavirus strains associated with gastroenteritis in water buffalo (Bubalusbubalis) calves. Vet. Microbiol. 145: 245-251.

Elia, G., Fiermonte, G., Pratelli, A., Martella, V., Camero, M., Cirone, F. and Buonavoglia, C. (2003). Recombinant M protein-based ELISA test for detection of antibodies to canine coronavirus. J. Virol. Methods. 109: 139-142.

Ellis, J., Anseeuw, E., Gow, S., Bryan, H., Salb, A., Goji, N., Rhodes, C., Coste, S.L., Smits, J. and Kutz, S. (2011). Seroepidemiology of respiratory (group 2) canine coronavirus, canine parainfluenza virus, and Bordetella bronchiseptica infections in urban dogs in a humane shelter and in rural dogs in small communities. Can. Vet. J. 52: 861-68.

Evermann, J.F., Abbott, J.R. and Han, S. (2005). Canine corona virus-associated puppy mortality without evidence of concurrent canine parvovirus infection. J. Vet. Diagn. Invest. 17: 610-614.

Graham, R.L. and Baric, R.S. (2010). Recombination, reservoirs, and the modular spike: mechanisms of coronavirus cross-species transmission. J. Virol. 84: 3134-3146.

Gur, S., Gencay, A. and Dogan, N. (2008). A Serologic investigation for canine corona virus infection in individually reared dogs in central Anatolia. J. Fac. Vet. Med. Univ. Erciyes. 5: 67-71.

Hansa, A., Rai, R.B., Wani, M.Y. and Dhama, K. (2012). Patholology and diagnosis of corona virus infection in bovine. Indian J. Vet. Pathol. 36: 129-135.

Huxsoll, D.L., Kaneshima, T., Hohdatsu, T., Satoh, K., Takano, T., Motokawa, K. and Koyoma, H. (2006). The prevalance of a group 2 coronavirus in dogs in Japan. J. Vet. Med. Sci. 68: 21-25.

Keenan, K.P., Jervis, H.R., Marchwicki, R.H. and Binn, L.N. (1976). Intestinal infection of neonatal dogs with canine coronavirus 1-71: Studies by virologic, histologic, histochemical and immunofluorescent techniques. Am. J. Vet. Res. 37: 247-256.

Lai, M.M.C. and Holmes, K.V. (2001). Coronaviridae: The viruses and their replication. In: Fields Virology, [Knipe, D.M., Howley, P.M. and Griffin, D.E., editors]. Lippincott Williams \& Wilkins, Philadelphia, USA; pp. 1163-1185.

Lau, S.K., Woo, P.C., Li, K.S., Huang, Y., Tsoi, H.W., Wong, B.H., Wong, S.S., Leung, S.Y., Chan, K.H. and Yuen, K.Y. (2005). Severe acute respiratory syndrome coronavirus-like virus in Chinese horseshoe bats. Proc. Natl. Acad. Sci. U.S.A. 102: 14040-14045.

Le Poder, S. (2011). Feline and Canine Coronaviruses: Common genetic and pathobiological features. Adv. Virol. Article ID 609465.

Mochizuki, M., Sugiura, R. and Akuzawa, M. (1987). Micro-neutralization test with canine corona virus for detection of corona virus antibodies in dogs and cats. Nihon Juigaku Zasshi. 49: 563-565.

Ntafis, V., Xylouri, E., Mari, V., Papanastassopoulou, M., Papaioannou, N., Thomas, A., Buonavoglia, C. and Decaro, N. (2012). Molecular characterization of a canine coronavirus NA/09 strain detected in a dog's organs. Arch. Virol. 157: 171-175.

Ntafis, V., Mari, V., Decaro, N., Papanastassopoulou, M., Pardali, D., Rallis, T.S., Kanellos, T., Buonavoglia, C. and Xylouri, E. (2013). Canine coronavirus, Greece. Molecular analysis and genetic diversity characterization. Infect. Genet. Evol. 16: 129-136.

Pratelli, A. (2011). The evolutionary processes of canine coronaviruses. Adv. Virol. Article ID 562831.

Priestnall, S.L., Mitchell, J.A., Walker, C.A., Erles, K. and Brownlie, J. (2014). New and emerging pathogens in canine infectious respiratory disease. Vet. Pathol. 51: 492-504.

Slingenbergh, J.I., Gilbert, M., de Balogh, K.I. and Wint, W. (2004). Ecological sources of zoonotic diseases. Rev. Sci. Tech. 23: 467-484.

Tuchiya, K., Horimoto, T., Azetaka, M., Takahashi, E. and Konishi, S. (1991). Enzyme-linked immunosorbent assay for the detection of canine corona virus and its antibody in dogs. Vet. Microbiol. 26: 41-51.

Zicola, A., Jolly, S., Mathijs, E., Ziant, D., Decaro, N., Mari, V. and Thiry, E. (2012). Fatal outbreaks in dogs associated with pantropic canine coronavirus in France and Belgium. J. Small Anim. Pract. 53: 297-300. 